\title{
Ethnocultural Identity in the Works of Krasnoyarsk Artists
}

\author{
Maria A. Amosova ${ }^{a}$, Natalia P. Koptseva ${ }^{a^{*} \text {, }}$ \\ Alexandra A. Sitnikovaa ${ }^{a}$, Natalia N. Seredkina ${ }^{a}$, \\ Yulia S. Zamaraeva ${ }^{a}$, Anastasia V. Kistova, ${ }^{\text {a, }}$, \\ Ksenia V. Reznikova ${ }^{a}$, Maria A. Kolesnik ${ }^{a}$ \\ and Natalia N. Pimenova ${ }^{a}$ \\ ${ }^{a}$ Siberian Federal University \\ 79 Svobodny, Krasnoyarsk, 660041, Russia \\ ${ }^{b}$ Krasnoyarsk Art Museum named after V.I. Surikov \\ 36 Karl Marks Str. / 20 Parizhskoi Kommmuny Str., \\ Krasnoyarsk, 660049, Russia
}

Received 07.07.2019, received in revised form 02.08.2019, accepted 09.08.2019

The article scrutinizes the problem of understanding and presenting the ethnocultural identity of the indigenous peoples in the works of art. The authors describe the features of the image visualization regarding the indigenous peoples of the North in the works of artists of the Krasnoyarsk Krai. For this purpose there was made a thorough analysis of the most representative works in painting and graphics, namely, Konstantin Voynov's painting "The Madonna Beyond the Polar Circle" (2009), Andrei Lekarenko's painting "The Girl from Taimyr" (1959) and Valery Kudrinsky's picture "The Northgirl” (1985). The analysis was based on the constructivist approach to identity and the principles of the modern theory of the fine arts stated by V.I. Zhukovsky and N.P. Koptseva. As a result, the researchers identified 1) three key stages of the Krasnoyarsk artists' interest in painting the indigenous peoples of the North (starting from the beginning of the $20^{\text {th }}$ century and ending at the beginning of the $21^{\text {st }}$ century); 2) two main approaches to depicting the lifestyle of the indigenous peoples of the North (documentary-ethnographic and philosophical ones).

Keywords: ethnocultural identity, Arctic, indigenous peoples of the North, fine arts, Krasnoyarsk Krai, Krasnoyarsk artists.

Research area: art studies; culturology.

(c) Siberian Federal University. All rights reserved

* Corresponding author E-mail address: decanka@mail.ru

ORCID: 0000-0003-3910-7991 (Koptseva); 0000-0003-1299-6741 (Zamaraeva); 0000-0002-1622-2797 (Sitnikova); 0000-0001-8194-7869 (Kolesnik); 0000-0002-9248-8810 (Seredkina); 0000-0002-0622-4465 (Pimenova); 0000-0002-5309-4616 (Kistova)

This work is licensed under a Creative Commons Attribution-NonCommercial 4.0 International License (CC BY-NC 4.0). 
Citation: Amosova, A.A., Koptseva, N.P., Sitnikova, A.A., Seredkina, N.N., Zamaraeva, Yu.S., Kistova, A.V., Reznikova, K.V., Kolesnik, M.A., Pimenova, N.N. (2019). Ethnocultural identity in the works of Krasnoyarsk artists. J. Sib. Fed. Univ. Humanit. soc. sci., 12(8), 1524-1551. DOI: $10.17516 / 1997-1370-0463$.

\section{Introduction}

Today, the problem of preserving the cultural memory and cultural heritage of ethnic communities is acute for the world culture. Modern technologies and the process of globalization lead to the unification of cultures and the loss of the unique cultural heritage of many ethnic groups. These processes make scientists address the issue of indigenous identity. The concept of "indigenous identity" and methods of its creation are analyzed in multitudinous publications (Baklanov et al., 2010; Makeev, Patrakova, 2004; Lebedeva, 1999; Tatarko, Lebedeva, 2011; Malygina, 2016 et others). P. Singh draws attention to the relationship between the ethnic and indigenous identities, indicating that the second is not a subset of the first and also mentioning that the most important issue of indigenous ethnic groups is their place in the national-state structure, the state policy towards them (Singh, 2018). B. Jacobs examines the factors affecting the indigenous identity, its types, legal and regulatory norms concerning the indigenous identity (Jacobs, 2019). D. Quigley raises the question of constructing the indigenous identity (social, racial and cultural one), investigating it by her own example: she looks into how identification processes differ in childhood and adulthood (Quigley, 2019). T. Hogan and P. Singh discuss the results of a round table devoted to socio-economic and cultural practices related to the preservation of the indigenous identity in the modern world and held between researchers who study the indigenous peoples and the representatives of the indigenous peoples from Australia and the Philippines (Hogan, Singh, 2018). M.G. Phillips and G. Osmond explore the indigenous identity on the basis of opposing process, i. e. assimilation, which gained the greatest spread in Australia in the mid $-20^{\text {th }}$ century. The authors consider various forms of assimilation, including that occurring in aboriginal institutions, and how they affected the indigenous identity (Phillips, Osmond, 2018).

The indigenous identity of the Nenets people and its transformation during the development of the tourism industry are studied by T. Gorbuntsova, S. Dobson and N. Palmer (Gorbuntsova et al., 2018). A number of studies are devoted to the relationship between the indigenous identity and indigenous languages; the examples 
used include the Inuit language (Moore, 2019); the Enets language (Reznikova et al., 2018), the Evenki language (Zamaraeva, 2018; Seredkina, 2018b), and the languages of the indigenous minorities in general (Seredkina, 2018a).

The research of the indigenous ethnocultural groups in the Krasnoyarsk Krai involves various scientific disciplines: social (cultural) anthropology (Kistova et al., 2016; Koptseva and Kirko, 2014a, 2014b, 2014d, 2014c; Koptseva and Reznikova, 2015; Koptseva et al., 2017; Reznikova et al., 2016; Reznikova et al., 2017; etc.), culture studies, art studies, economics (Sertakova et al., 2016) and pedagogy (Seredkina and Smolina, 2018b). For the purposes of this scientific article we focused on cultural studies and art studies mainly.

M. Kolesnik, N. Libakova and E. Sertakova comprehensively studied art education in the north of the Krasnoyarsk Krai, including its role in shaping the ethnocultural identity of the indigenous peoples of the North (Kolesnik et al., 2018). G. Fedorov reviews the connection between educational practices (schoolchildren studying reindeer husbandry) and the indigenous identity on the example of Yakutia (Fedorov, 2018) and V. Anthony-Stevens with P. Stevens do the same in the context of "reterritorialization" and the creation of mixed schools (Anthony-Stevens, Stevens, 2017).

One of the key areas of preservation and development of the ethnocultural identity is fine art, therefore, the scientific analysis of artworks for the purpose of studying the inherent cultural memory of ethnic groups is becoming extremely topical today.

M. V. Moskalyuk (Moskalyuk, 2010), T.M. Lomanova (Lomanova, 2005), A. V. Fedotova (Fedotova, 2010) and others turn to the analysis of the creative works of Siberian artists. A. A. Sitnikova (Semenova, 2011) analyses the A. Surikov's works in the context of the Siberian image. N.N. Seredkina regards the construction of the indigenous identity through art (Koptseva, Nevol'ko, 2012; Seredkina, 2015; Sitnikova et al., 2018). K. A. Bulak (Bulak, 2014) scrutinises the works of Krasnoyarsk artists who have devoted themselves to depicting the North.

Representatives of more than 150 nationalities live within the borders of the Krasnoyarsk Krai, so it is not surprising that since the end of the $19^{\text {th }}$ century the works of Krasnoyarsk artists have demonstrated a persistent interest in representing the cultural identity of the indigenous peoples of Siberia and the North, whether these were sketches from expeditions to remote areas of the region, portraits, genre pictures depicting everyday life and household details, as well as generalized visual images revealing the ontological foundations of the life of the indigenous peoples. These very artworks eulogizing the indigenous peoples have a high sociocentric value, so they 
can be seen as a form for the preservation and reproduction of the indigenous identity associated with the everyday life of the indigenous people, the ways of traditional economy and thinking about the world, a special spiritual mentality, moral and religious traditions of ethnic groups.

\section{Methods}

The results were achieved with the help of methods of bibliographic analysis, which were used to study key scientific approaches to and existing theoretical concepts of the topic of indigenous peoples in fine arts, as well as with the help of methods of philosophical and art analysis developed by V.I. Zhukovsky and N. P. Koptseva, which were used for the interpretation of representative imagery in the art history of Krasnoyarsk.

\section{Ethnocultural identity of the indigenous peoples: definition}

\section{of the concept}

The essential concept of the present study is the ethnocultural identity of the indigenous peoples, which is understood as the process of individual's conscious choice of their own belonging to a particular ethnic group, sharing and promoting the cultural values of this group, as well as its worldview, which leads to their self-opposition to other ethnic communities. At the same time, the ethnic community itself has a specific goal and cultural value, namely to preserve and support this ethnos. The formation of the indigenous identification starts in childhood and continues even when a person gets old. The indigenous identification is a stable form of social identification. However, the ethnic identity of the indigenous peoples undergoes various changes after contact with other ethnic communities. It is impossible to predict today what effect this contact will have on the identification of a specific ethnocultural group in future.

Thanks to the state policy aimed at active supporting the indigenous peoples in the Russian Federation, the responsible specialists take measures to maintain the indigenous identity. These measures include organization of various art exhibitions that take place in museums and galleries exhibiting works of the indigenous peoples or works of artists whose pictures depict ethnic communities and their cultural characteristics. Artists, who show the life of the indigenous peoples, attract public attention to the current problems of these ethnic groups. In addition, the artists themselves take part in the creation of indigenous identity via conjuring its signs, images and symbols in their works. 


\section{Specificity of the visual images of the indigenous peoples of the North} in the artworks made by Krasnoyarsk artists

The pictures of the North and the image of the indigenous peoples are intrinsic parts of the works painted by Krasnoyarsk artists, whose interest in this topic may be caused by the virginity of the northern land, its non-accessibility for industrial processes. They prefer to show nature with wide and mighty rivers, soft moss, different berries with unforgettable distinctive taste, white blinding snow, animals that live in harmony with the indigenous peoples, the amazing dwellings of the indigenous peoples, their temperament, religion and customs that are reverentially kept by modern representatives of the indigenous ethnocultural communities. All the above mentioned characteristics contrast with the harsh and severe conditions of life and the rules that the merciless nature imposes on a person living in this territory.

The object of the study is some selected artworks made by Krasnoyarsk artists, who pay heed to the topic of the northern indigenous peoples' life. The list of such artists is quite long, since the North makes up most of the Krasnoyarsk Krai, where the indigenous minorities live, and also due to the fact that artistically gifted people find it impossible to remain indifferent to this unbeaten ethnocultural and natural space.

One of the first Krasnoyarsk artists who addressed the topic of the indigenous peoples of the North was Dmitry Innokent'evich Karatanov (1874-1952), who was inspired by his teacher - M. A. Rutchenko. On the advice of Vasily Ivanovich Surikov, he set off to study under Arkhip Ivanovich Kuindzhi in the Imperial Academy of St. Petersburg. After training, he returned to Krasnoyarsk and took part in expeditions across Siberia with the team of ethnographers working in the Krasnoyarsk Regional Museum of Local Lore (several trips to the lower reaches of the Yenisei river, to the Far North, the Middle Yenisei and the Ob river from 1917 to 1940s). In his works, D. I. Karatanov paid great attention to the northern landscapes and the way of life of the indigenous peoples. Most of his works are graphic ones made during the expeditions. These are sketches and pencil drawings, owing to convenience of these types of art for constant movements and the availability of art materials in field conditions. Despite that many Karatanov's works are sketches, they present pervasive artistic techniques corresponding to the advanced artistic trends of that time, for instance, combining several phases of movement of the same character in one image (Smolin, 2013), "frameby-frame" deployment of action, showing movement via artistic devices. Karatanov's works are of great interest from the point of view of the documentary and ethnographic approach to fixing the peculiarities of people's life in the north. His works are recognized 
by images of traditional boats, fishing gear, methods of cooking fish, etc. Karatanov's works portray the Kets as an example of the indigenous peoples of the Krasnoyarsk Krai. One of the most integral works of the artist is the work "Nansen's Expedition" in 1936 (Fig. 1), dedicated to the famous journey of the Norwegian polar explorer Fridtjof Nansen in 1913 on the steamer "Correct" through the Kara Sea along the Yenisei river to Krasnoyarsk. The expedition of F. Nansen had a goal to open the Northern Sea Route, overcome the myth of the impassability of the Kara Sea and find a passage from Siberia to Europe. During his trip, the researcher wrote the book "To the Country of the Future", where he described the enormous prospects for the development of Siberia after the discovery of this sea route by virtue of new opportunities for sharing rich resources with other countries. This Karatanov's work visually represents the essence of F. Nansen's journey: first, the painter used his signature technique: the frame-byframe happening of the action from the depths to the outside, which marks the idea of how the Norwegian explorer is moving closer to Siberia; secondly, the painter included the attributes of a polar expedition: a covered with frost ship, faithful companions laikas, local guides and a discoverer himself, who is taking a hard look at new horizons (not only geographical, but also mental) by using binoculars and scientific equipment.

The outstanding Krasnoyarsk artist Andrey Porfir'ievich Lekarenko (1895-1978) was taught by D. I. Karatanov, perhaps, therefore, their pictures are similar in genre specifics. On completing his studies, he began to create his own paintings, making numerous trips around the Krasnoyarsk Krai and other regions of Siberia. From 1926 to 1928 , A. P. Lekarenko lived on Taimyr, taking part in the population census; then

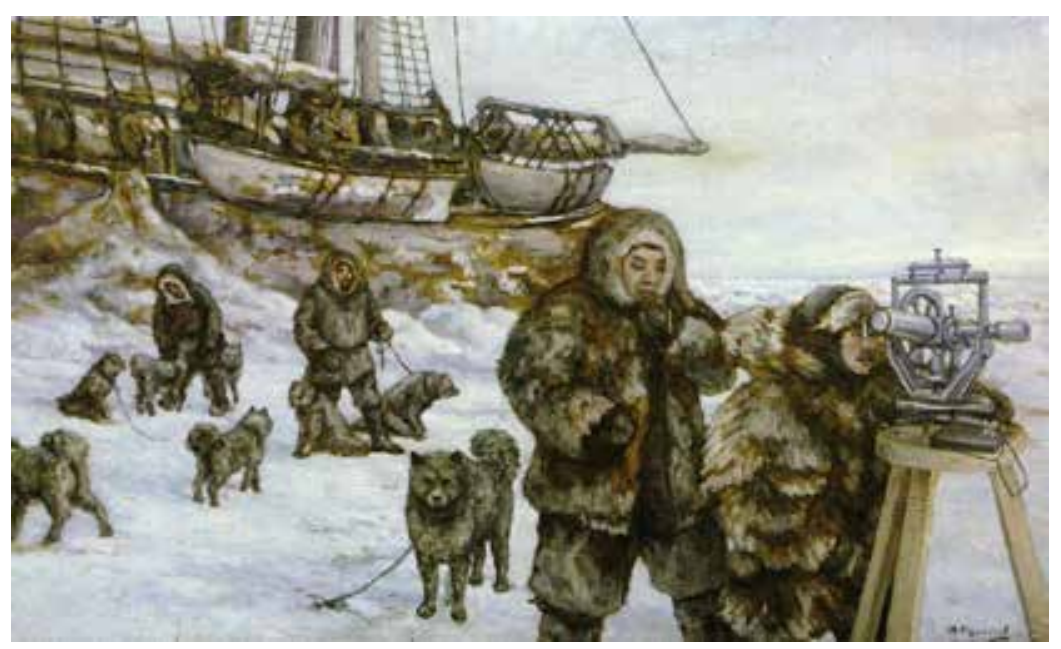

Fig. 1. D. I. Karatanov. Nansen's Expedition. 1936 


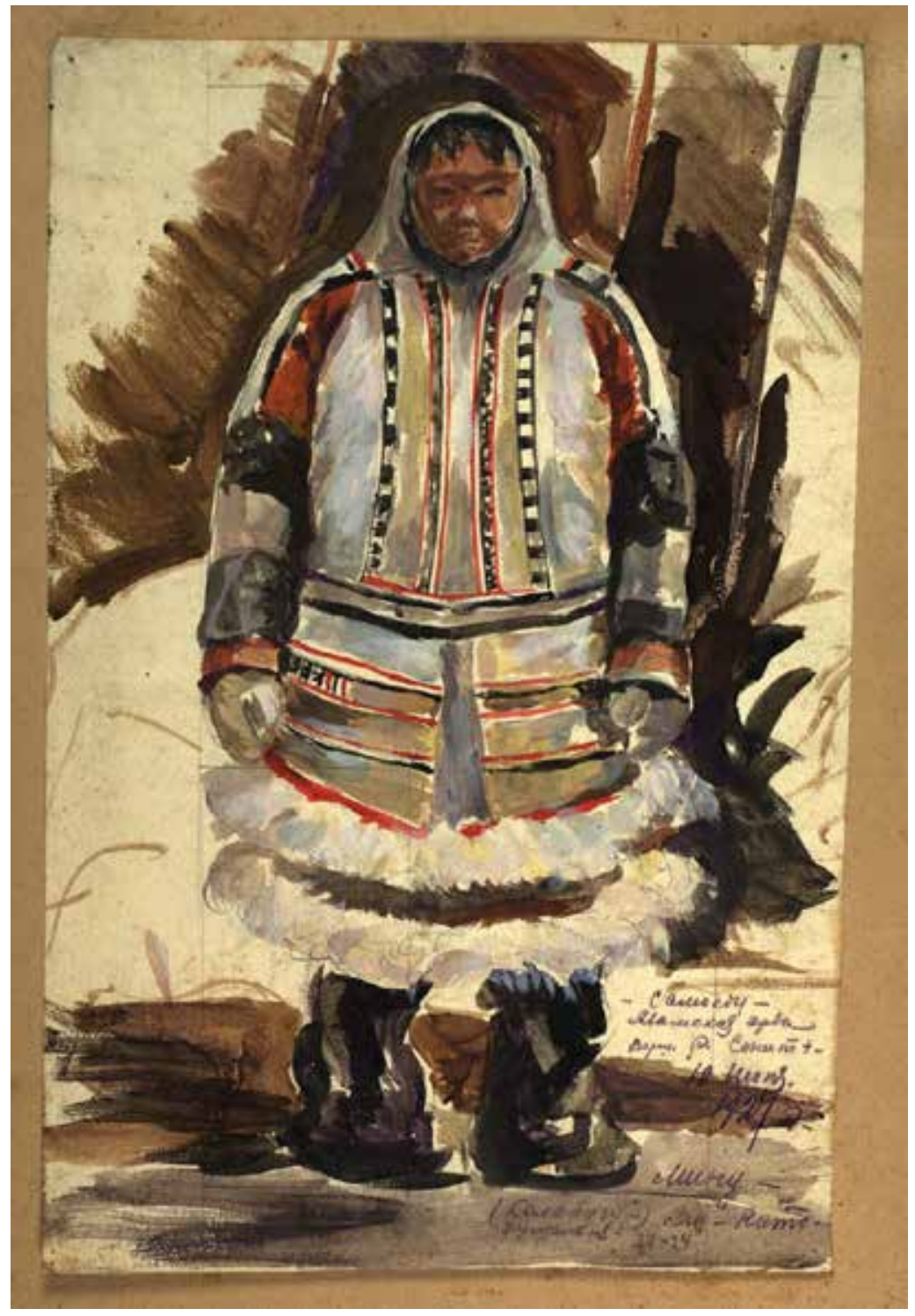

Fig. 2. A. P. Lekarenko. Malitsa of the Avam Samoyeds. 1927

he lived for a long time with the Nganasans. As a result, the artist brought back a great deal of works portraying ethnic communities of the indigenous peoples. The artistic and ethnographic value of these works was recognized by the highest USSR authorities. For example, in the picture "Malitsa (jumper) of the Avam Samoyeds" (Fig. 2), one can see a representative of the Nganasan people in traditional clothes made of deer skins with characteristic geometric patterns, which proves the high documentary significance of the Lekarenko's work, although many other works of the artist also have indispensable high artistic merit: the painter studied the opportunities of the northern 
colouristics (monochrome, with a predominance of blue and ochre shades), creation of a generalized image of the indigenous peoples (blurred facial features and, in a contrast, an elaborate draughtsnmanship of the details of everyday life and clothing, which indicates a high sustainability and uniformity of the material embodiment of the Nganasan culture).

Both D. I. Karatanov and A.P. Lekarenko as artists-thinkers have one thing in common, which is the appeal to ethnography, manifested in an exceptional number of works on ethnocultural themes.

Images of the northern Siberian nature are also found in the landscape works of the artist Boris Yakovlevich Ryauzov (1919-1994) who worked in the war and post-war time. B. Ya. Ryauzov graduated from the Omsk Art College where he was taught by T.P. Kozlov. In 1946 he moved to Krasnoyarsk. In the 1950s, he travelled to Turukhansk and created the "Turukhansk series" of eight landscapes (Fig. 3); in the 1970s he went to the Arctic, in particular, he visited the town of Dudinka, and consequentially presented paintings on northern themes at an academic exhibition in 1976.

It is known that B. Ya. Ryauzov was a front-line artist, his works painted in the trenches captured the dramatic moments of the Great Patriotic War (World War II): the exploits of N. Gastello and A. Matrosov, the ruts from the tanks on the road, the explosions; but even these works give an impression that the artist was constantly interested in aesthetic issues of colouristics, the relations between colours. Northern landscapes by B. Ya. Ryauzov (who is called the "Siberian impressionist", as he used the tone value technique and contemplated on the problem of the relationship between heavenly and earthly colors) are distinguished by the variety of shades of white (a complicated system of differences in snow conditions is typical of northern peoples), the originality of the monotonous unity of skies and ground in the North. With his works created in Dudinka and in the village of Igarka, the master draws the focus towards the abnormal invasion of river cranes and ships in the ports, both of which bring in alien colours into the northern monotony (Fig. 4).

A new surge of interest in the northern themes occurred in the 1960s. A plenty of artists began to create works in the so-called "stern style". The North is a space of courageous hunters and fishermen, thick, difficult-to-walk-through forests, a place where travellers go to experience the full force of nature, its steadfastness and endurance of a man in extreme conditions. During this period, such artists as Gennady Georgievich Gorensky (1938-2009), Anton Arkad'evich Dovnar (1939-2005), and 


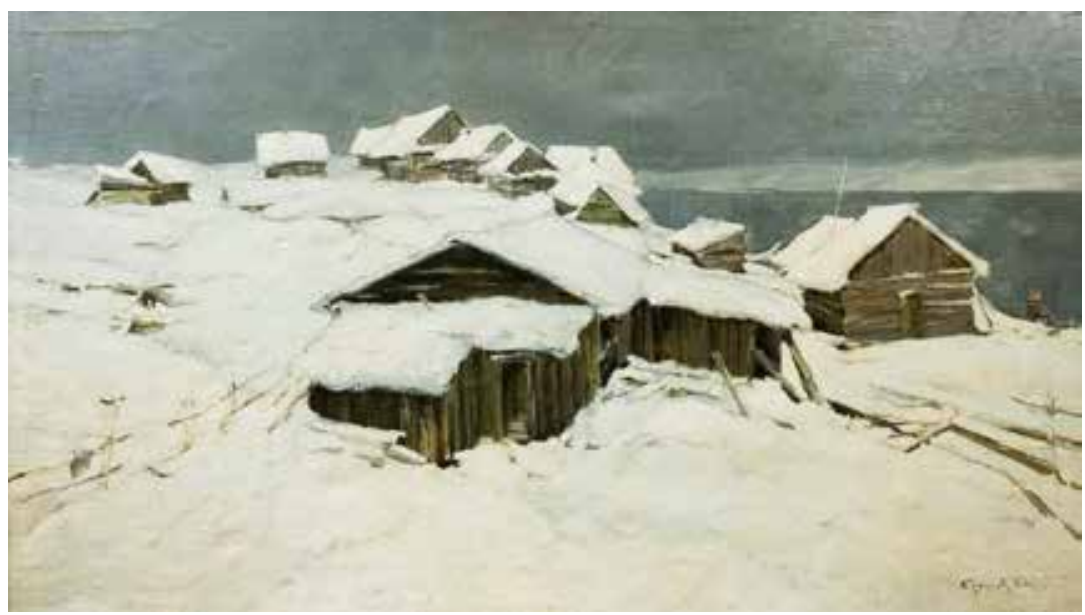

Fig. 3. B. Ya. Ryauzov. Old Turukhansk at the Mouth of the Lower Tunguska. The Historical Place of Exile of I. V. Stalin, Ya. M. Sverdlov, S. S. Spandaryan.1951

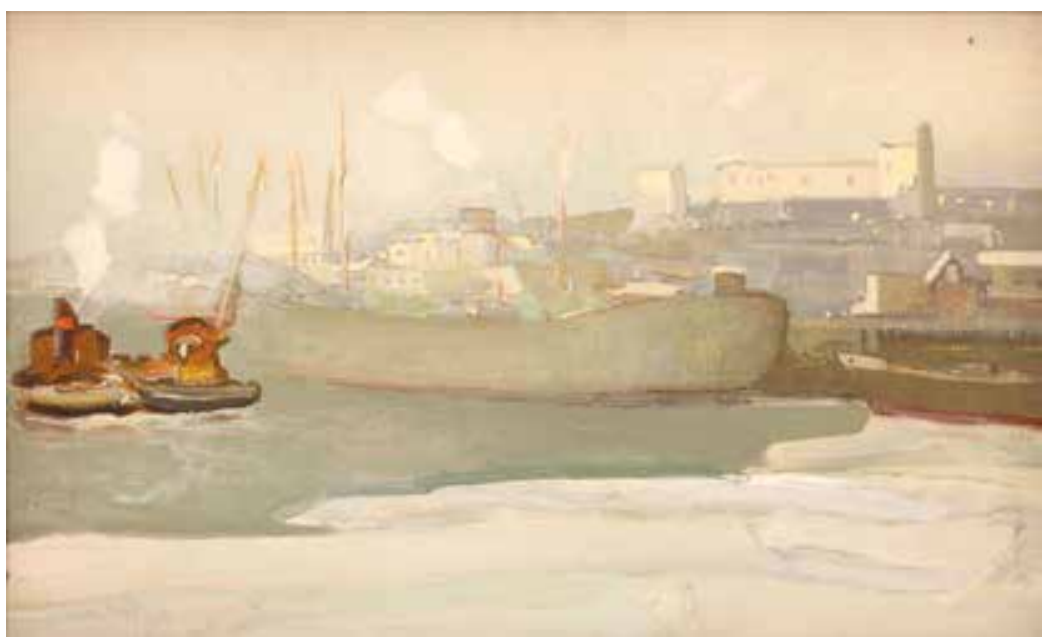

Fig. 4. B. Ya. Ryauzov. In the Backwater. 1973

partly Vladimir Feofanovich Kapel'ko (1937-2000) and others began to get excited by the North.

Anton Arkad'evich Dovnar graduated from the Krasnoyarsk Art College named after V. I. Surikov in 1964. After that, he was assigned to teach Art at a school in the village settlement of Taloye in the Irbeysky district. Working as a school teacher, he did not stop creating his own works. Later, he returned to Krasnoyarsk with plentiful paintings.

The artist expands the boundaries of the specific northern genres and begins to paint images of animals, taking more and more interest into them. The famous picture 


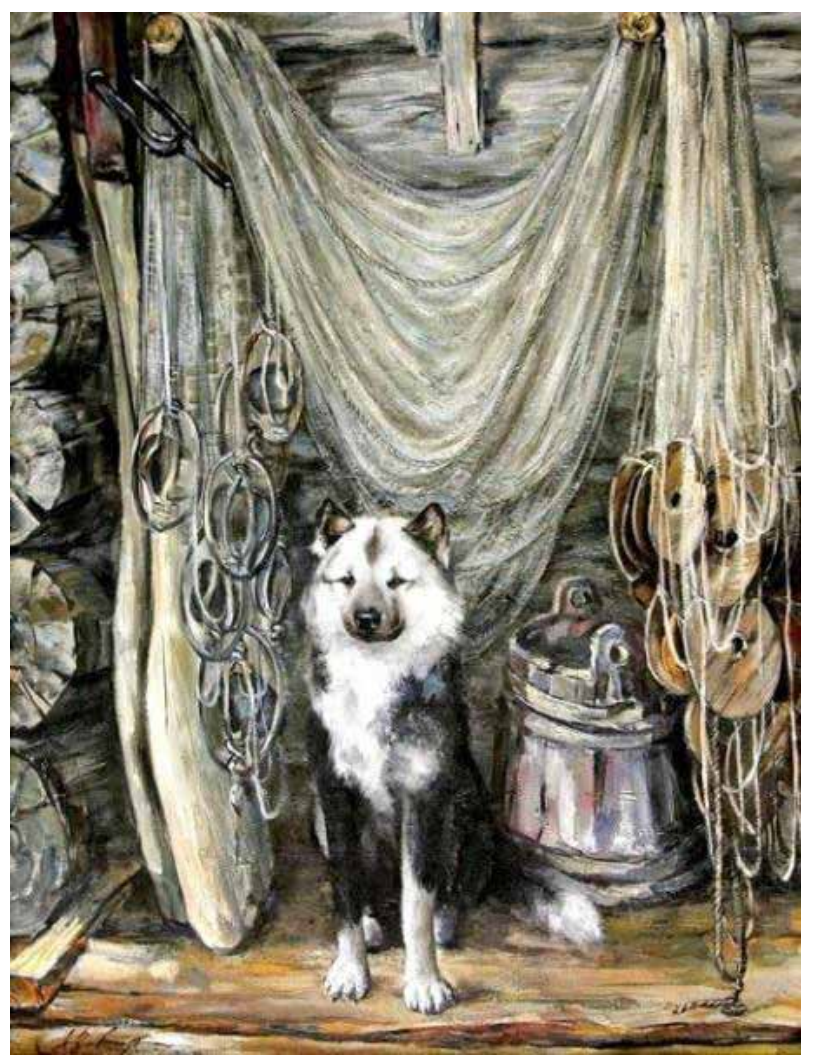

Fig. 5. A. A. Dovnar. My friend - Uchum. 1988

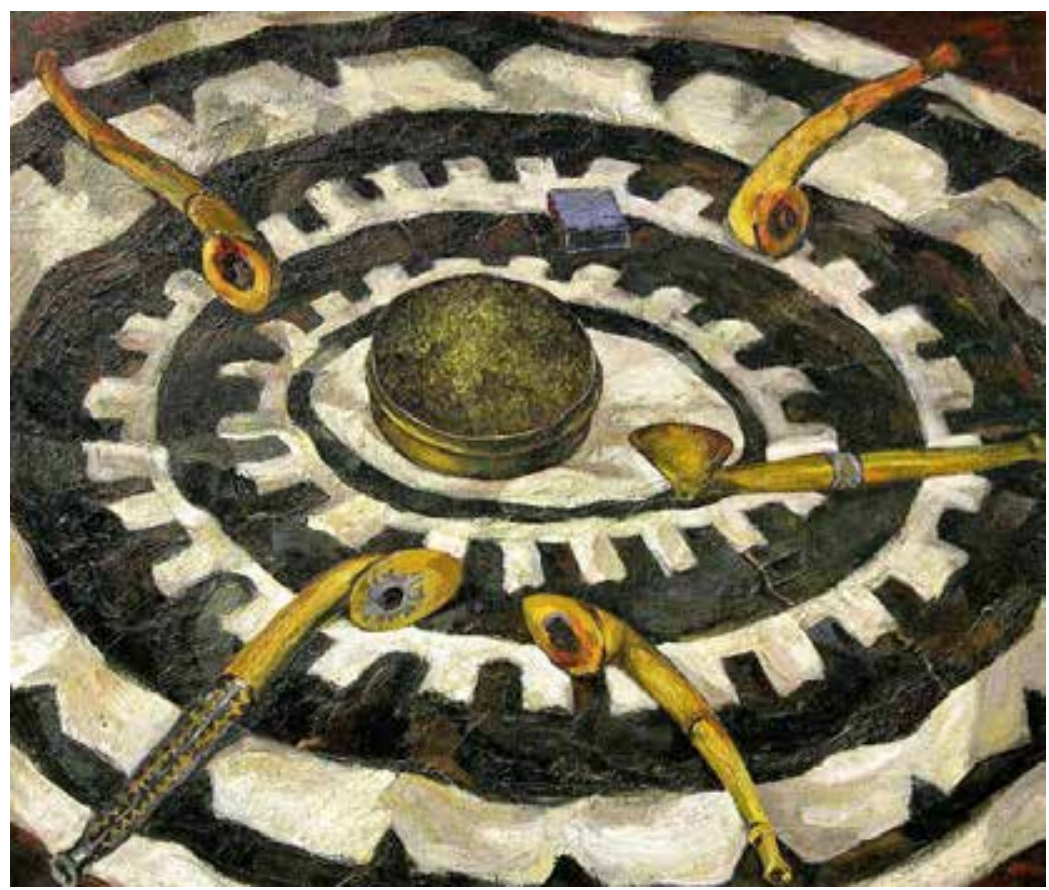

Fig. 6. A. A. Dovnar. The Nganasan Pipes. 1973 
of Anton Arkad'evich Dovnar "My friend - Uchum" (Fig. 5) is a portrait of the main indigenous comrade and a helper in hunting and fishing in northern conditions - a laika dog surrounded by fishing tackle (Fig. 5). A. A. Dovnar grants a new life to household items of the northern peoples and tells their story like a wizard-storyteller: in the picture "The Nganasan Pipes" (1973) (Fig. 6) the individuality of the residents of the Nganasan village is conveyed through a variety of forms and traditional design of pipes that are an intrinsic part of meetings for meditative rest, which is emphasized by the carpet's laconic geometric pattern typical of the decorative and applied arts of the Nganasans.

Gennady Georgievich Gorensky was born in 1938. In 1958-1963 he studied at the Krasnoyarsk Art College named after V.I. Surikov. The features of the "stern style" were most clearly represented in the works of this artist. He travelled extensively in the Krasnoyarsk North, visited the Polar Station, in particular, among his works there are portraits of representatives of the Nenets - a small indigenous people. The group portrait of Nenets fishermen creates the image of modern aborigines of the north, where the traditional features of the Nenets culture (parkas, fishing) are combined with the attributes of civilization penetrating to the north (a canister with gasoline, kirza boots). The picture below (Fig. 7) demonstrates all the characteristic features of the "stern style": a large format, a frontal pose of a person for the portrait, the figures occupying the whole space, a strict and focused look at the viewer. In the group portrait, the people of all generations are united: one can see adults, experienced fishermen, a teenager and a boy of school age. Painted against the background of snow, wrapped in warm and ascetic (plain) clothes, "plunging" their heads in fishing boats, as into the craft of their life, these northerners make the audience compare such difficult living conditions with their urban comfort.

One of the most distinctive Krasnoyarsk artists of the post-war generation, Vladimir Feofanovich Kapel'ko, graduated from art school in 1958, and in 1963 he graduated from the Krasnoyarsk Art College named after V.I. Surikov. After that, he made frequent trips to Evenkia, to Taimyr, Chuysky trakt (Chuya highway), to Khakassia, Tuva, rafted down the rivers Angara and Yenisey, travelled around Sakhalin, the Baltics, was to Crimea. Despite the fact that in the end of his travels he showed an affinity of his artistic language to the primitive drawings of the indigenous peoples of Khakassia and did not show any particular interest in the northern expanses, there are several paintings with images of northern life in his work. Being an artist V.F. Kapel'ko was primarily interested not in ethnographic details, but in light effects. 


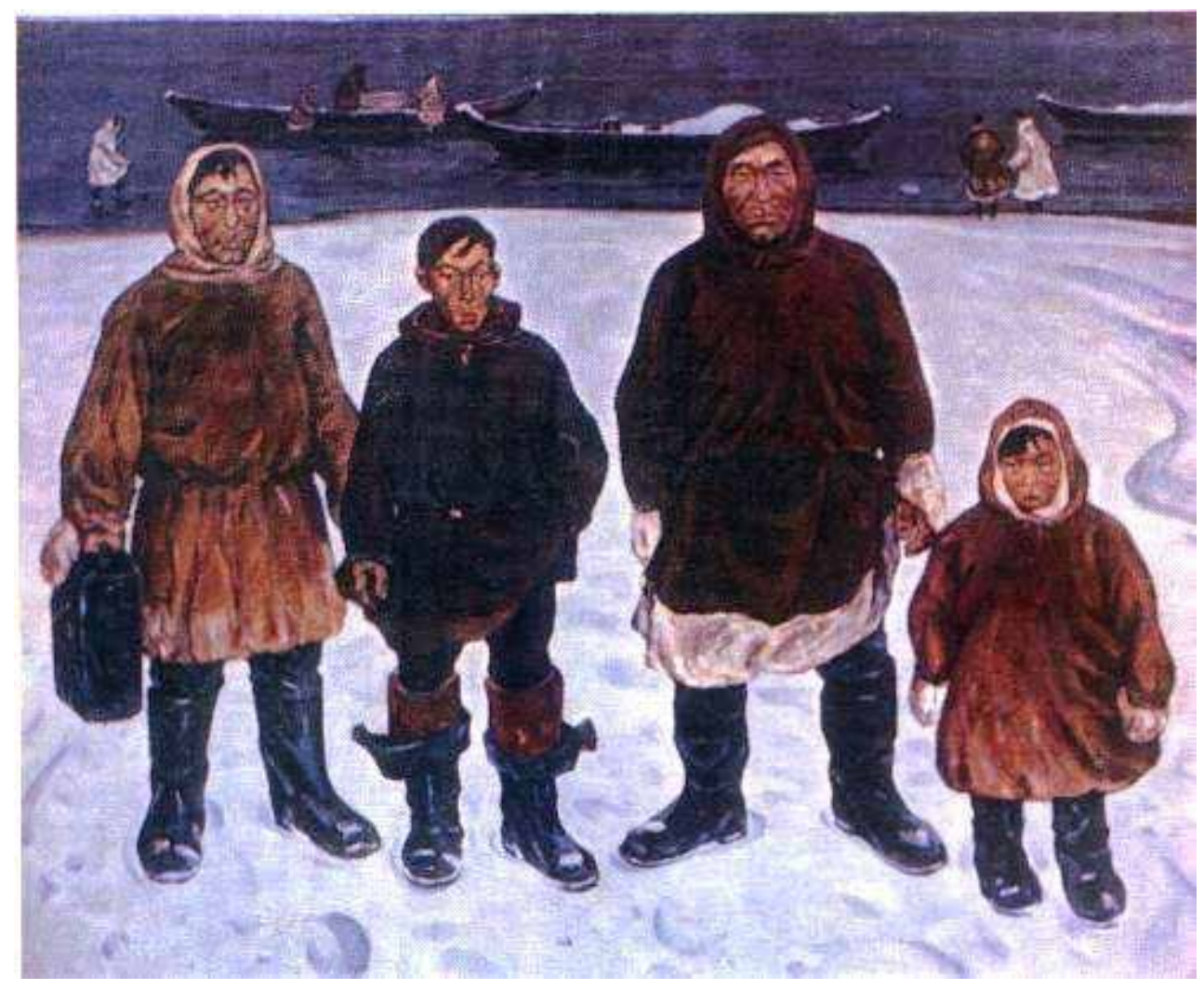

Fig. 7. G. G. Gorensky. The Nenets Fishermen. 1972

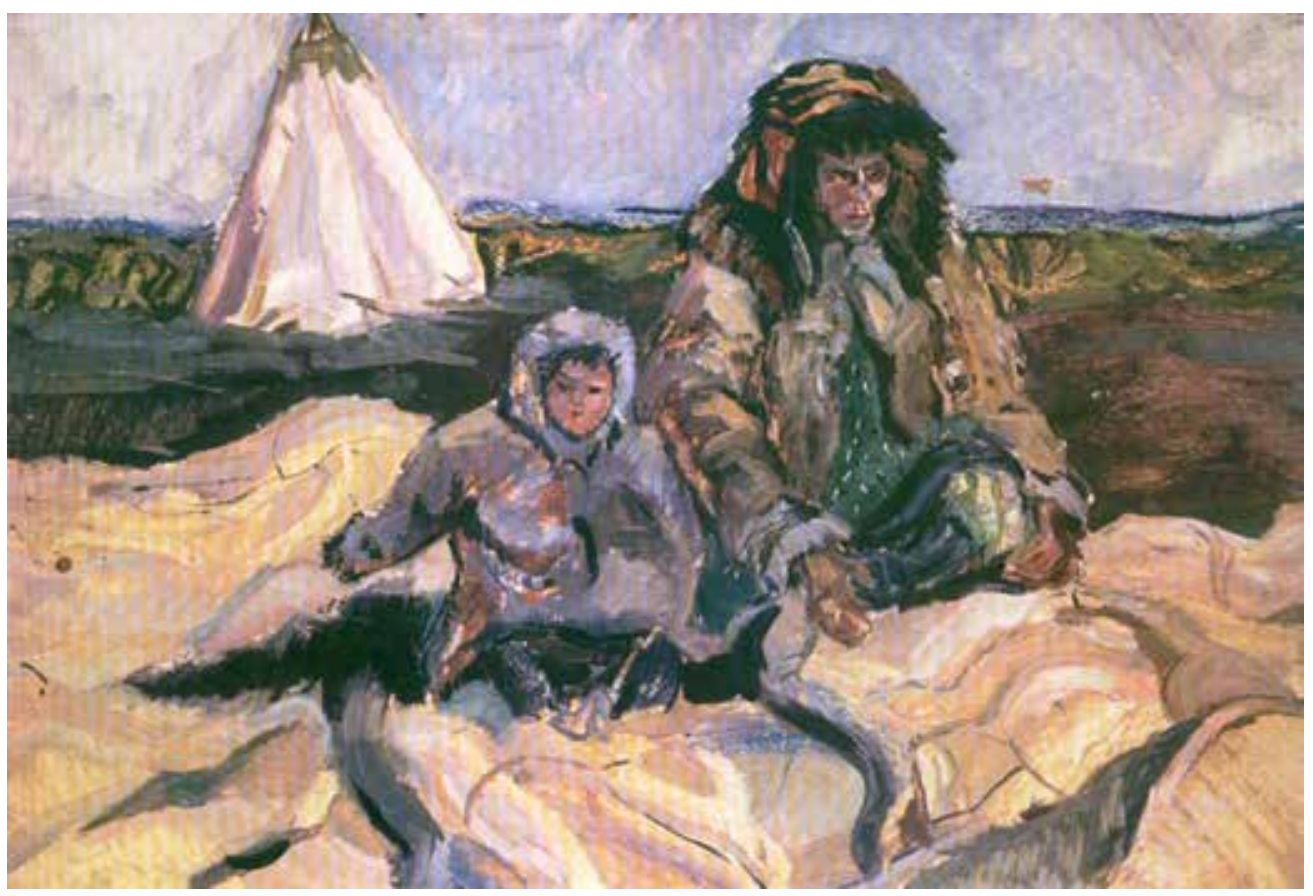

Fig. 8. V.F. Kapel'ko. Father and Son near the Chum. 1962 
Indeed, the northern lights, the polar nights and days, the high intensity of sunlight enhanced by snow cover are also core objects of the interest of painters who depict the North (Fig. 8).

The original Krasnoyarsk artist Valery Borisovich Roslyakov, who passed away too early, was born in 1952 in the town of Dudinka, Krasnoyarsk Krai, and later graduated from the Krasnoyarsk Art College named after V. I. Surikov and the Russian Academy of Arts. Since he was born in the North, this topic was very close to him, he devoted many of his works to the North and Dudinka in particular. Art critics believe (Bulak, 2014) that his work is characterized by a nostalgic interpretation of the plots. Even on his small canvases one can see images of the greatheartedness of the northern peoples. Thanks to his artistic thinking, the impression is created that the indigenous peoples are dear to him, and that is why he painted their images with special pleasure.

For his "northern" paintings V. B. Roslyakov preferred sombre colours, unlike other Krasnoyarsk artists. Silver-gray colour dominates in his pictorial works. His paintings convey the search for the image of a person who needs peace and quiet (Fig. 9).

One of the most important subjects in the culture of the indigenous peoples of the North is a deer: in addition to being a source of food and heat (making clothes and chums from deerskin), deer becomes a widespread image used in art, while ornate patterns on deer antlers become the basis for the traditional clothing decoration, and

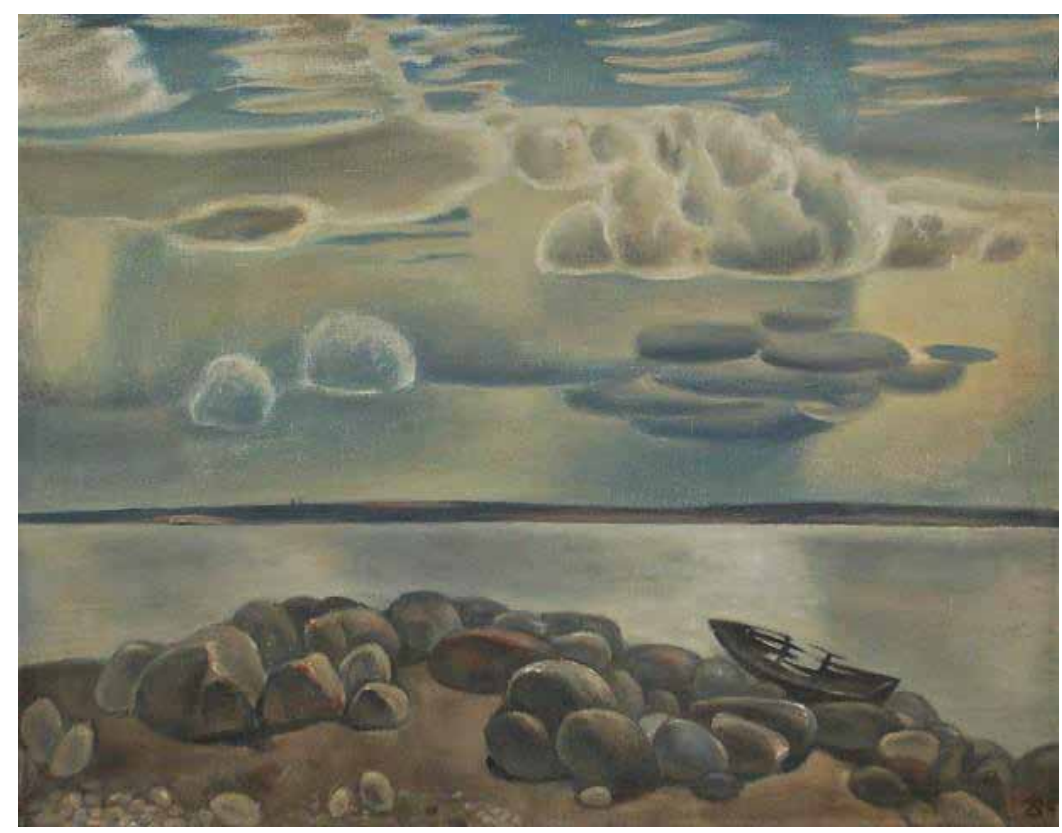

Fig. 9. V.B. Roslyakov. Memories of the North. 1984 


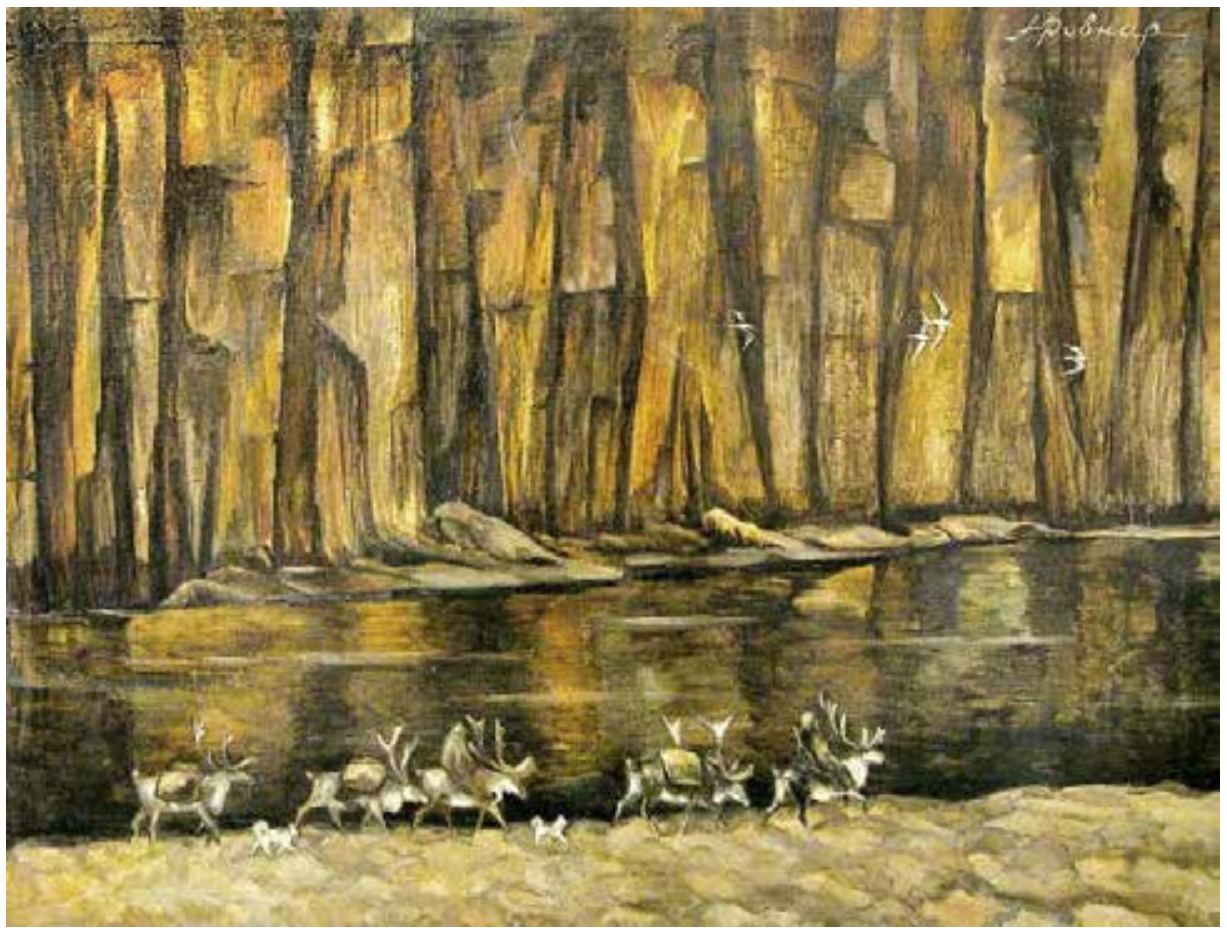

Fig. 10. A. A. Dovnar. In the Putorana Plateau. 1978

also for the decoration of household items and similar. It is not accidental that deer and deer argishs (movements of deer herds and carts across the tundra) are often painted by Krasnoyarsk artists - A. A. Dovnar (Fig. 10), V. I. Meshkov, etc.

The history of painting the life in the North by Krasnoyarsk artists would be incomplete without mentioning the Krasnoyarsk-Finnish painter Toivo Vasil'evich Ryannel (1921-2012), who in his work strived to present the most epic, that is related to the archetypical ones, images of the Krasnoyarsk Krai. Moreover, he also investigated the phenomenology of the Krasnoyarsk north and created such epic paintings as "Mountain Cedars" (1959), "Birth of the Yenisei" (1958). To paint the latter he travelled and visually examined the Krasnoyarsk Krai from north to south, visiting Igarka, lower reaches of the Yenisei river, the Sayan mountains, Tuva, Khakassia and Taimyr. In the north, he accompanied geological expeditions, so the images of the North that appeared in his work are connected, on the one hand, with images of explorers of the northern territories, and, on the other hand, with unique features of sunlight in the North, which he could not but convey being an artist (Fig. 11).

Pictures of the North of the modern Krasnoyarsk painter Konstantin Semenovich Voinov (Fig. 12) are, first of all, a philosophical revelation about man. And only secondarily he tried to imprint the national details of the life of the peoples of the North; 


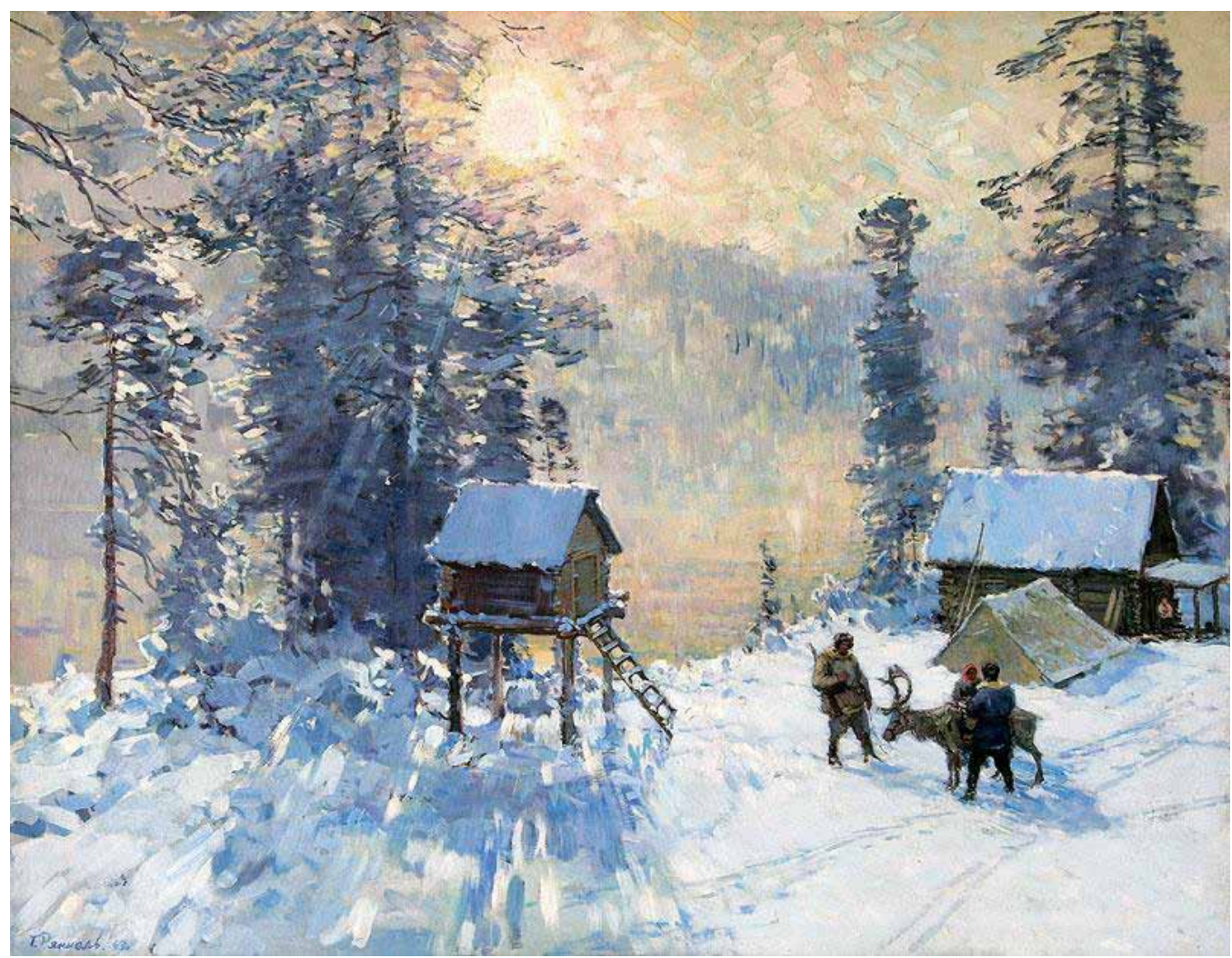

Fig. 11. T. V. Ryannel. The Trading Post at the Podkamennaya Tunguska. 1963

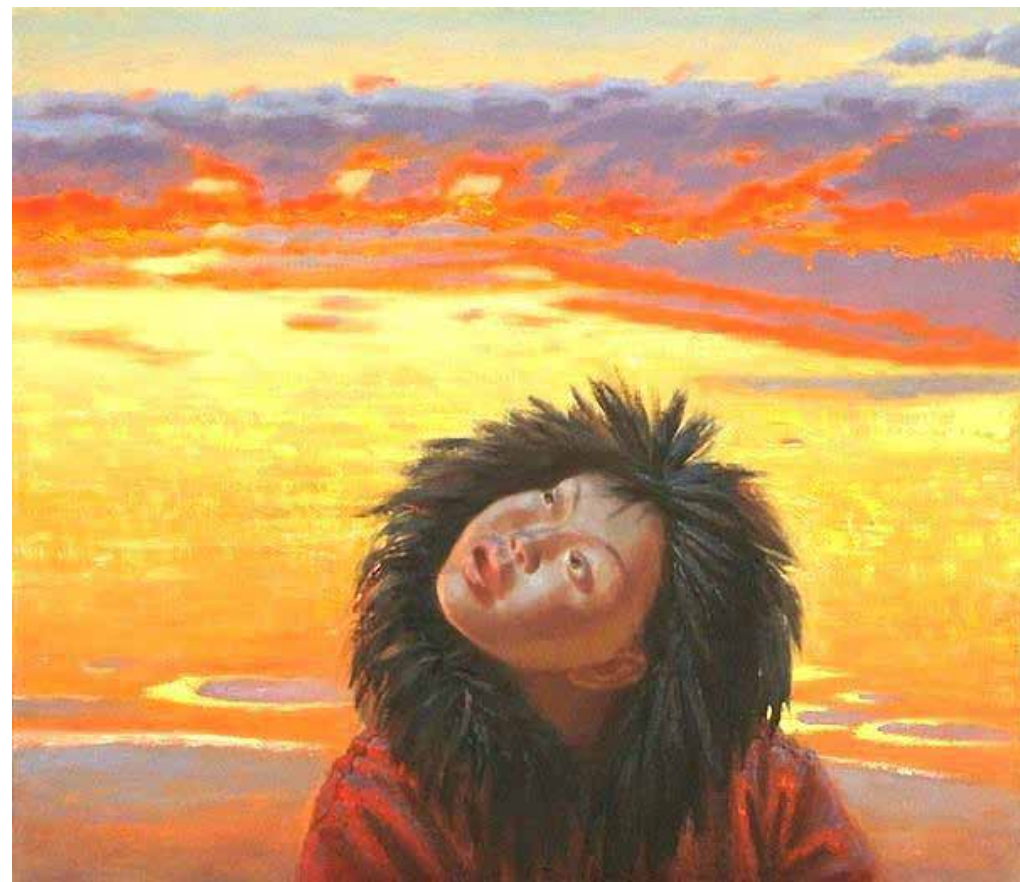

Fig. 12. K. S. Voinov. Miracles. 2011 
most often these were ethnic portraits, authentic costumes and decorative ornaments, folk and kinship festivals and rituals.

Konstantin Semenov Voinov was born in 1960 in Usol'ka village in Krasnoyarsk Krai. In 1983 he graduated from the Krasnoyarsk Art College named after V. I. Surikov, and in 1989 - from the Krasnoyarsk State Art Institute where he studied painting.

His interest in the North was reinforced by a trip to the upper reaches of the Yenisei river - a traditional source of inspiration for artists of the region. Naturally, the unparalleled light of the North, at least the brightest sun during the polar day, and open empty spaces with a far-reaching horizon line are all natural paintings that any oil and canvas worker wants to observe. Apart from that, Konstantin Voinov studied the details of northern life with the help of the daguerreotypes of early research expeditions, which are stored in the Krasnoyarsk Regional Museum of Local Lore, and using cultural and historical materials about everyday life, traditions and customs of the indigenous small-numbered peoples of the region. This research resulted in a whole series of graphic works, which presented the original traditions of twelve nationalities living on the territory of the region: the kin's deer of the Evenks, clay ovens and cooking bliny (pancakes) of the Chuvash people, the Chukchi life, migrating by deer, etc.

The North in the paintings of Konstantin Voinov is, first of all, represented by the people who inhabit it. These people do not admire the northern landscapes, yet, the painter used extremely bright light effects and depicted the movement of clouds, both of which elevate all reflections to cosmic scales. Due to the application of all the classical methods of painting, austere compositions, images are easily perceived and understood by the viewer.

One of the central themes of his paintings was the life of the indigenous peoples of the Krasnoyarsk Krai. In these pictures he painted not so much the everyday details but rather the symbolic meaning. He used to say that looking at the traditional clothes of the indigenous peoples, upon careful examination, one can discern the ideas of different ethnic groups about life, death, world, their dreams, and the history of their ancestors. Traditional things of the indigenous peoples make up one wholesome picture, telling what their being, values, traditions are.

Furthermore, in Voinov's works there are also religious and philosophical interpretations: for example, some scenes of northern life can be put together with traditional canons of presenting biblical events. This is especially evident in the painting "The Madonna beyond the Polar CIrcle", where not only the name, which allows drawing a parallel with religious history, but the very scene of feeding a child by a woman in 
dokha (a fur-coat on both sides), which rounds the mother to spherical universal fullness, are sacred. And in the painting "The White Parka" one can find parallels with the plot of the Annunciation: a blessed ray of light highlights a woman doing ordinary homework: she is mending the traditional hooded jacket (called parka). And the painting "Miracles" develops the theme of the relationship between nature and a man: here a little Evenk child admires nature as a picture; probably it is a birth of a new artist who will be seized with the endless desire to represent the glow of the sky with azure, gold and scarlet flashes, for example, in abstract canvases, which, oddly enough, are based on real events.

The themes of the indigenous identity are characteristic not only of Krasnoyarsk painting, but also of Krasnoyarsk graphic art. Vladimir Il'ich Meshkov (1919-2012) was a master of linocuts (Fig. 13). During the Soviet era he was sent to work as an artist to Evenkia to work for the newspaper "Evenkiiskaia Novaia Zhizn"” (Evenki New Life). It happened in 1939, when the Evenki people practically did not speak Russian, so the main content for the newspaper was the Meshkov's drawings, which were comprehensible to everyone without words. Undoubtedly, for the newspaper he mostly created everyday sketches about the life of the Evenki people. His coloured linocuts are far more famous. There he presented nature; the deer - hosts of those places; hunters with dogs, northern lights. First of all, the Meshkov's works are known for their artistic merit, as they are shiny monochrome linocuts with frequent colourful

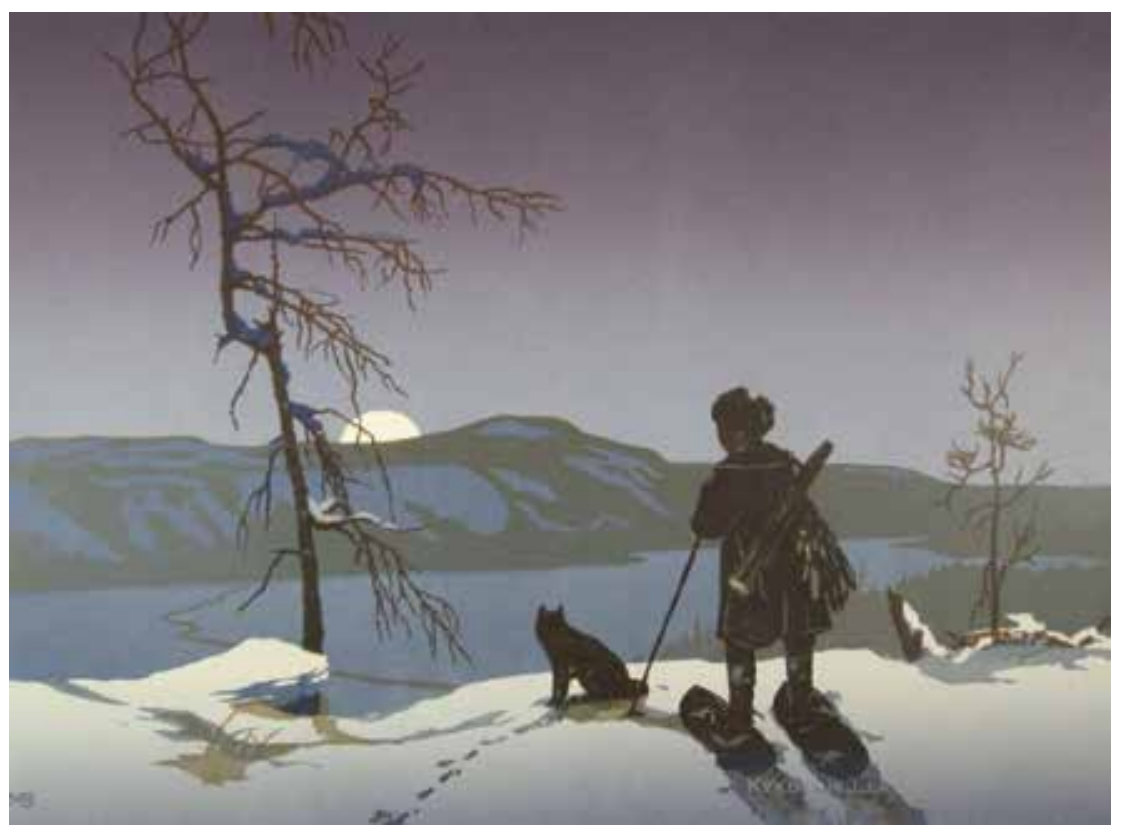

Fig. 13. V. I. Meshkov. The Hunter's Contemplation. 1967 
spots - the northern lights or the huge northern sun with divergent circles of light, and all the characters are subject to the strict compositional rules.

While in the $20^{\text {th }}$ century, especially in the first half of the $20^{\text {th }}$ century, ethnographic details of the northern life were in demand as regards painting and art in general, and artists took part in research expeditions, for no visual impression to remain forgotten, today, in the $21^{\text {st }}$ century, the documentary fixation of ethnographic images is done by photographers who also make creative work and accompany scientific expeditions on a mandatory basis. The number of Krasnoyarsk artists taking part in expeditionary trips, therefore, declined at the beginning of the $21^{\text {st }}$ century, instead original and independent artists began to appear in the places of residence of the indigenous peoples. The following examples can be mentioned to confirming this thesis:

- in 2007, with the support of the Prokhorov Foundation, the Krasnoyarsk Museum Centre "Ploshchad' Mira" carried out the photo project "The Counter Motion". The idea of the photo project was to present the contrasts between the southern and northern life in the Krasnoyarsk Krai in photographs: a Moscow photographer Alexander Sorin went to Khakassia and Tuva to take pictures of yurts, shamanistic practices and steppes, and a Krasnoyarsk photographer Alexander Kuznetsov set off to Norilsk and the polar regions, where he captured the aboriginal ethnic groups of the north, their traditional holidays (reindeer feast) and the industrial development of the North.

- Among the professional artists of the North of the Krasnoyarsk Krai, the Nganasan artist Motiumiaku Turdagin received the greatest fame (he graduated from the Krasnoyarsk Art School).

Certain stages can be distinguished in the way Krasnoyarsk artists and researchers represented the ethnocultural identity and the visual specifics of the North in the history of the Krasnoyarsk fine arts in the $20^{\text {th }}$ and $21^{\text {st }}$ centuries:

1) The first half of the $20^{\text {th }}$ century, when ethnographic and documentary direction dominated in the painting and graphics of Krasnoyarsk authors, when artists participated in research expeditions, first of all, in order to embed the visual details of northern life. They sketched the attributes of everyday life, traditional ethnic clothing, fishing gear, etc. Artistic problems (compositional solutions, the effects of lighting, the impact of the image on the audience) faded into the background in such works, but still had a certain significance.

2) In the second half of the $20^{\text {th }}$ century, the depiction of the North, the study of the epic qualities of the Krasnoyarsk north still remained a paramount task for Krasnoyarsk artists, but, going north, they are finally involved, above all, in artistic 
tasks: they create images in the aesthetics of "stern style", parade the epic strengths of northern nature, etc.

3) Now, at the beginning of the $21^{\text {st }}$ century, Krasnoyarsk artists' interest in the theme of the North is declining, although some artists successfully continue their work on revealing the philosophy of the North, drawing analogies between the culture of the North and other cultures (K. Voinov). Photography takes on the function of documenting the northern life, whereas among the indigenous peoples themselves there appear professional artists who are able to visualize the specificity of ethnocultural identity in their own works of art.

\section{Analysis of visual images representing the ethnic and cultural specifics of the Krasnoyarsk Krai north}

Representatives of more than 150 nationalities live on the territory of the Krasnoyarsk Krai; in addition, representatives of eight indigenous small-numbered people of the North live there (if we include the Yessey Yakuts in this list, then the number of such peoples accounts for 9). The indigenous peoples and their life in the North has always been an attractive topic for Krasnoyarsk artists. Such a diversity of ethnic communities could not but draw the attention of artists, so they would go on expeditions to represent the indigenous way of life and the traditional religious faith of peoples in their works of art. The indigenous identity is created, inter alia, through the perception of works made by famous Krasnoyarsk artists, whose source of inspiration is the abundant material and spiritual culture of the indigenous peoples, the sui generis northern nature, and the transformations of northern space.

The study of the artworks which have been made by Krasnoyarsk artists and which are devoted to various aspects of the indigenous identity is relevant for many reasons, among which are the following theoretical principles:

1) artworks are the peculiar "keepers" of knowledge about the values, standards, traditions of the indigenous peoples. They create imagery for the presentation of religious ideals and specific ethnocultural worldview;

2) artworks perform an educational function, as through the perception of artworks the recipient-viewer receives certain knowledge about the indigenous peoples and forms their own understanding of these peoples' being and culture;

3) artworks perform an instructional function, contributing to the creation of positive images for moral ideals: courage, stamina, respect for ancestors, love for animals, the preservation of family values and elements of ancient knowledge; 
4) the purposeful formation of the artistic space based on a specific theme and filled with concrete and consistent images allows the artworks to exert an ideological impact on society, with the special emphasis on critical issues of indigenous peoples.

For further analysis of the signs and imagery of the indigenous identity shown in the works of Krasnoyarsk artists, we chose the following works of fine art with the help of a preliminary inquiry: Konstantin Semenovich Voinov's painting "The Madonna beyond the Polar Circle” (Fig. 14), Andrey Porfir'evich Lekarenko's painting "The Girl from Taimyr" (Fig. 15) and the picture by Valery Innokent'evich Kudrinsky "The Northgirl" (Fig. 16). These artworks have one common feature, which is the use of female images for the representation of any particular implication of the indigenous identity.

Thus, it is possible to identify some signs and imagery typical of the visual embodiment of the indigenous identity, presented in three female images in the pictorial works made by Konstantin Semenovich Voinov, Andrey Porfir'evich Lekarenko and Valery Innokent'evich Kudrinsky. To create a female image these artists use the image of warm fur traditional parkas, which display sundry inserts and ornaments that have their own specific meaning depending on the ethnic group. All paintings depict women with facial features characteristic of the indigenous population (narrow eyes with a

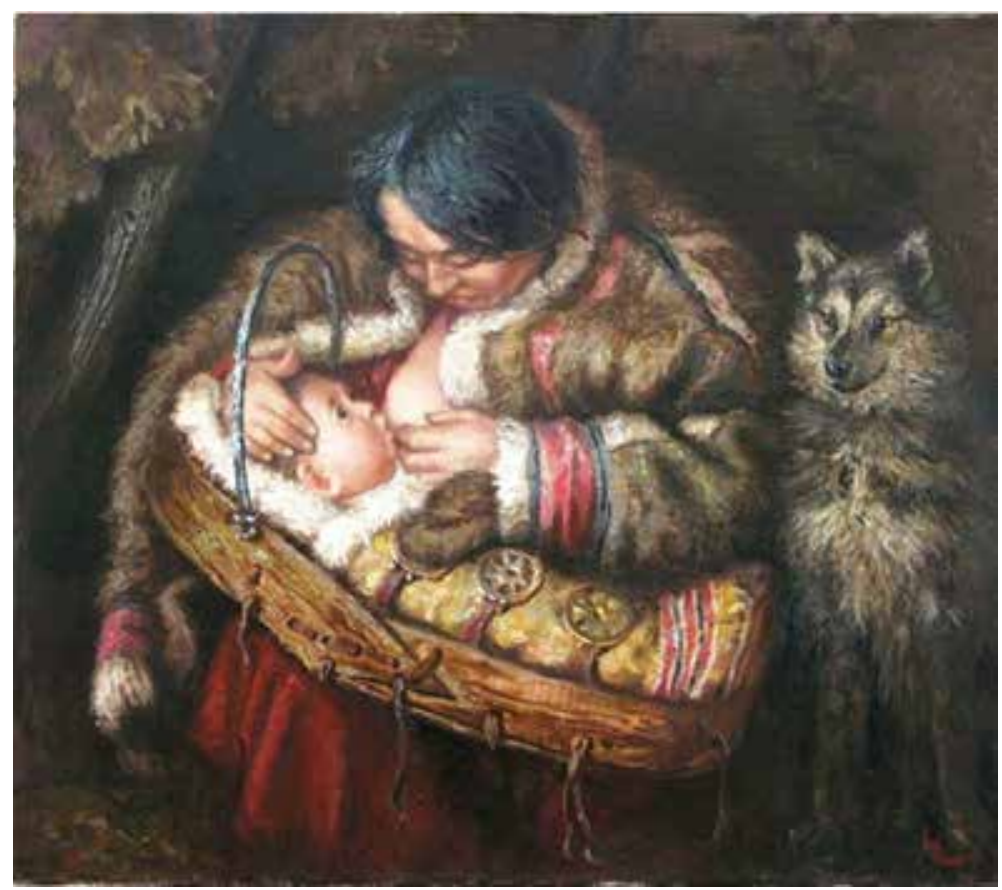

Fig. 14. K. S. Voinov. The Madonna beyond the Polar Circle. 2009 


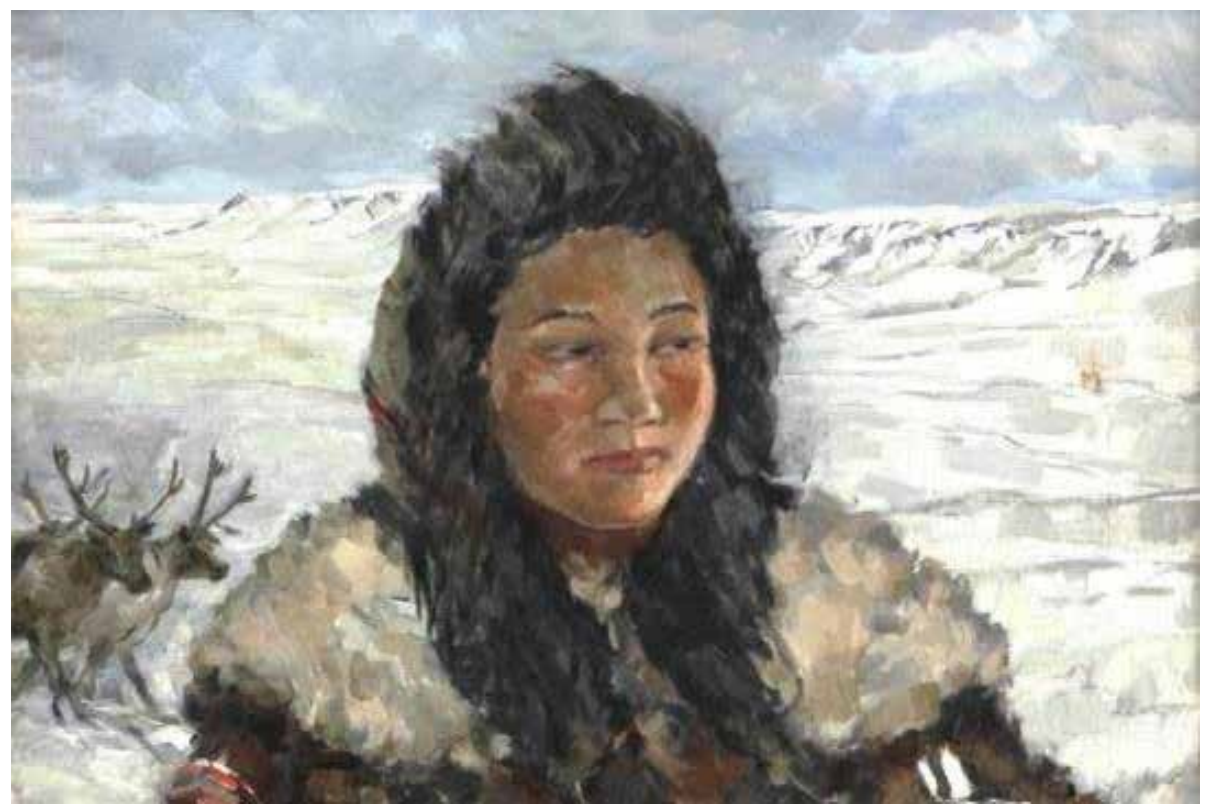

Fig. 15. A.P. Lekarenko. The Girl from Taimyr. 1959

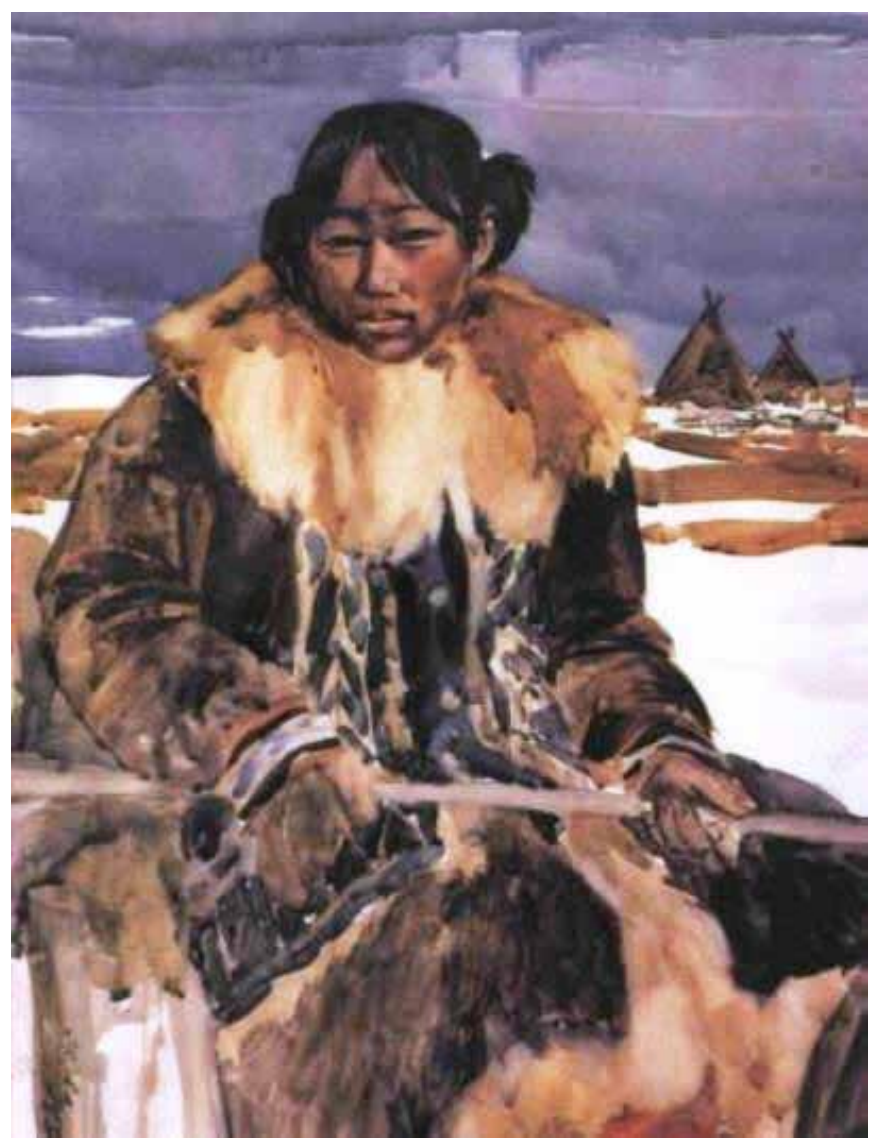

Fig. 16. V.I. Kudrinsky. The Northgirl. 1985 
hanging eyelid, swarthy skin, dark iris, dark hair). Artists form the representative image of the daily life of the indigenous population: these are nomadic peoples who are constantly in motion, who do not live long in one and the same place, with animals constantly accompanying them: deer, dogs that help them survive in northern conditions. Though the indigenous peoples are free, they do not live alone, because it is easier to overcome difficulties together. In all three artworks there is the image of snow, which facilitates recipients' understanding why the women are wearing these fur and quite heavy clothes: these images bear a special idea of low temperatures and too inclement conditions for life in the North.

\section{Conclusion}

In the Krasnoyarsk Krai not only scientists but also artists have always showed interest in the life of peoples who have inhabited the area of the Yenisei estuary. It can be concluded that in fine arts there have been formed two approaches to depicting the life of peoples of the North, one is documentary-ethnographic and the second is philosophical.

The documentary-ethnographic approach consists of a pictorial or graphic depicting of the details and attributes of the everyday life of a northern person. These are decorative patterns of traditional costumes, devices used for religious rituals, paintings of traditional fishery and reindeer herding. The artists who followed the ethnographic direction and painted the Krasnoyarsk Krai north were Dmitry Ivanovich Karatanov and Andrey Porfir'evich Lekarenko, who went on research expeditions to the north, lived among the Nenets, Nganasans and Dolgans, immersed themselves in the lifestyle of these people, sketched the traditional dwellings "chums", fishing, deer herds and so on and so forth.

A philosophical approach to understanding the lifestyle in the North througn painting is a sort of assertion about what is remarkable about this life; a way of thinking, enabling seeing clearly the original meanings in colourful ethnic details, the matrix of human existence, which, unfortunately, have been smoothed away by the atmosphere of modern cities. The artist offers an illustrative reflection on what this primordial purity of the people tells.

Based on the scientific reviews and special analyzes, it was concluded that the theme of ethnocultural identity in Krasnoyarsk art underwent three stages of development during the $20^{\text {th }}$ and $21^{\text {st }}$ centuries: 1 ) in the first half of the $20^{\text {th }}$ century, artists perform the role of documentalists and visual anthropologists; 2 ) in the second 
half of the $20^{\text {th }}$ century, artists' interest in northern images shifted to solving artistic problems (compositional, philosophical, connected with colouristics and plot); 3) in the beginning of the $21^{\text {st }}$ century, documentary photographers begin to perform the function of visual anthropologists, while the number of northern expeditions with the participation of artists is reduced.

Analyzes of artworks by Konstantin Semenov Voinov ("The Madonna beyond the Polar Circle"), by Andrei Porfir'evich Lekarenko ("The Girl from Taimyr") and Valery Innokent'evich Kudrinsky "The Northgirl" made it possible to conclude that women's images are especially characteristic of the northern and indigenous themes of the works of these artists.

The images of girls and women are endowed with specific external features, associated in everyday consciousness with the images of the indigenous peoples of the North. The action in the K. S. Voinov's painting "The Madonna beyond the Polar Circle" takes place indoors, and in the works by A. P. Lekarenko and V. I. Kudrinsky outdoors, against the northern landscape.

The artistic image of the painting "The Madonna beyond the Polar Circle" implies a certain integration of Christian and traditional northern religious ideals. Artistic images of girls painted by V.I. Kudrinsky and A.P. Lekarenko draw the viewer's attention solely to the traditional ethnocultural peculiarities of the life of indigenous peoples.

Female images develop in a certain dynamics: a teenage girl — a young girl - a woman and a mother. Krasnoyarsk artists focus the attention of viewers very precisely on the importance of the feminine origin in its various incarnations, which is typical of Mother Earth cults and the feminine origin as it is. Art forms chosen by Krasnoyarsk artists for the realization of the indigenous identity are based on the ethnographic method, yet, ethnographic content always undergoes artistic transformation and results in the creation of certain female symbols of the indigenous identity of the aboriginal peoples of the North.

\section{References}

Anthony-Stevens, V., \& Stevens, P. (2017). 'A space for you to be who you are': An ethnographic portrait of reterritorializing indigenous student identities. In Discourse, 38(3), 328-341.

Baklanov, I.S., Dushina, T.V., Makeeva, O.A. (2010). Chelovek etnicheskii: problema etnicheskoi identichnosti [Ethnic man: the problem of ethnic identity]. In Voprosy sotsial'noi teorii [Social theory issues], 4, 396-408. 
Bulak, K.A. (2014). Formirovanie i razvitie severnoi temy v tvorchestve khudozhnikov Krasnoiarskogo kraia [Introduction and development of the northern theme in the works of artists of the Krasnoyarsk Krai]. In $V$ mire nauki i iskusstva: voprosy filologii, iskusstvovedeniia i kul'turologii: sbornik statei XXXIII mezhdunarodnoi nauchno-prakticheskoi konferentsii [In the world of science and art: Issues of philology, art history and cultural studies: a collection of articles of the $33^{\text {rd }}$ international scientific and practical conference], 2 (33), 45-52. Novosibirsk.

Fedorov, G.M. (2018). Educational programs forming ethnocultural and regional identity in children of the indigenous peoples of the north and the Arctic. In Astra Salvensis, 6, 403-410.

Fedotova, A.V. (2010). Izobrazitel'noe iskusstvo v kul'turnom prostranstve Kol'skogo Severa v 1930-e [Fine art in the cultural space of the Kola Peninsula North in the 1930s]. In Obshchestvo. Sreda. Razvitie [Society. Environment. Development], 3, 151-154.

Gorbuntsova, T., Dobson, S., Palmer, N. (2018). Rural entrepreneurial space and identity: A study of local tour operators and "the Nenets" indigenous reindeer herders. In International Journal of Entrepreneurship and Innovation, 19(4), 261-272.

Hogan, T., Singh, P. (2018). Modes of indigenous modernity: Identities, stories, pathways. In Thesis Eleven, 145(1), 3-9.

Jacobs, B. (2019). Indigenous identity: Summary and future directions. In Statistical Journal of the IAOS, 35(1), 147-157.

Karlova, O.A., Koptseva, N.P. (2015). Novaya art-kritika na beregakh Eniseia: Monografiia [New art critics on the banks of the Yenisei river: Monograph]. Krasnoyarsk, SFU, 388 p.

Kistova, A., Pimenova, N., Reznikova, K., Zamaraeva, J., Koptseva, N., Seredkina, N., Filko, A. (2016). Place management: Decoding the visual image of a Siberian city. In Journal of Applied Economic Sciences, 11(6), 1143-1155.

Kolesnik, M. A., Libakova, N.M., \& Sertakova, E.A. (2018). Art education as a way of preserving the traditional ethnocultural identity of indigenous minority peoples from the North, Siberia and the Far East. In Novosibirsk State Pedagogical University Bulletin, 8(4), 233-247.

Koptseva, N.P., Nevol'ko, N.N. (2012). The national visual art in the process of formation and preservation of the ethnic identity of the indigenous peoples (on the example of Khakass fine art). In Journal of Siberian Federal University. Humanities \& Social Sciences, 8 (5), 1179-1198. 
Koptseva, N.P., Kirko, V.I. (2014a). Specificity of ethnogeny indigenous peoples by Central Siberia in the transition from the traditional type of society to modern society. In Life Science Journal, 11(7), 409-413.

Koptseva, N.P., Kirko, V.I. (2014b). The information basis for formation of positive ethnic identities in the process of acculturation of indigenous peoples of the Arctic Siberia (Krasnoyarsk, Russia). In Life Science Journal, 11(8), 479-483.

Koptseva, N.P., Kirko, V.I. (2014c). Ethic identification of indigenous people of the Siberian Arctic. In American Journal of Applied Sciences, 11(9), 1573-1577.

Koptseva, N.P., Kirko, V.I. (2014d). Modern specificity of legal regulation of Cultural Development of the Indigenous Peoples of the Arctic Siberia (the Altay Region, the Zabaikailsky Region, Republic of Buryatia, Russia). In Life Science Journal, 11(9), $314-319$.

Koptseva, N.P., Reznikova, K.V., \& Kirko, V.I. (2017). The Political Struggle for Evenkia's "Special Status" Within Krasnoyarsk Krai (Central Siberia). In Asian Politics \& Policy, 9(1), 99-121.

Lebedeva, N.M. (1999). Sotsial'naia identichnost' na postsovetskom prostranstve: ot poiskov samouvazheniia k poiskam smysla [Social identity in the post-Soviet space: from the search for self-esteem to the search for meaning]. In Psikhologicheskii zhurnal [Psychological Journal], 20 (3), 48-58.

Lomanova, T.M. (2005). Motivy etnoarkhaiki v iskusstve Sibiri (na primere tvorchestva krasnoiarskikh khudozhnikov. Ot oblastnikov do postsovetskogo perioda) [Ethno-archaic motifs in the Siberian art (on the example of the work of Krasnoyarsk artists. From regionalists to the post-Soviet period)]. In Piatye Omskie iskusstvovedcheskie chteniia "Sovremennoe iskusstvo Sibiri kak sobytie" [Fifth Omsk art history readings "Contemporary Siberian art as an event”]. Omsk, 10-14.

Makeev, S., Patrakova, A. (2004). Regional'naia spetsifikatsiia sotsiokul'turnykh razlichii v Ukraine [Regional specification of socio-cultural differences in Ukraine]. In Sotsiologiia: teoriia, metody, marketing [Sociology: theory, methods, marketing], 3, $109-125$.

Malygina, I.V. (2016). Mirovye tendentsii i rossiiskaia spetsifika dinamiki etnokul'turnoi identichnosti [World tendencies and the Russian specificity of ethnocultural identity dynamics]. In Vestnik Moskovskogo gosudarstvennogo universiteta kul'tury $i$ iskusstv [Bulletin of the Moscow State University of Culture and Arts], 5 (73), 42-53.

Moore, S. (2019). Language and identity in an indigenous teacher education program. In International Journal of Circumpolar Health, 78(2). 
Moskalyuk, M.V. (2010). Vsie, chto v serdtse. Khudozhniki Krasnoiaria vchera, segodnia, zavtra [Everything, that is in the heart. Artists of Krasnoyarsk yesterday, today, tomorrow]. Krasnoyarsk, Polikor, 288 p.

Phillips, M.G., \& Osmond, G. (2018). Marching for assimilation: Indigenous identity, sport, and politics. In Australian Journal of Politics and History, 64 (4), 544-560.

Quigley, D. (2019). Indigenous identity construction: Enacted upon us, or within us. In Social Identities, 25(5), 694-703.

Reznikova, K., Seredkina, N., Koptseva, N., \& Zamaraeva, J. (2016). Regional specifics of social values and their impact on Central Siberian territories' modernization (based on research of Krasnoyarsk region). In Economic Annals-XXI, 160(7-8), 92-95.

Reznikova, K.V., Seredkina, N.N., Zamaraeva, Y.S., \& Koptseva, N.P. (2017). The traditional economy of indigenous peoples of central Siberia (the case of the Selkups). In International Journal of Economic Research, 14(15), 261-270.

Reznikova, K.V., Zamaraeva, Y.S., Sergeeva N.A. (2018). The Sociocultural Problems of Teaching the Entsy Language. In Journal of Siberian Federal University. Humanities \& Social Sciences, 7(11), 1137-1150.

Semenova, A.A., Bralkova, A.V. (2011). Vizualizatsiia kontsepta "sever" v izobrazitel'nom iskusstve [Visualization of the concept "north" in fine arts]. In Journal of Siberian Federal University. Humanities \& Social Sciences, 4 (4), 476-491.

Semenova, A.A., Soshenko, M.V. (2011). Image of Siberia in Alexander Surikov's Works. In Journal of Siberian Federal University. Humanities \& Social Sciences, 4 (12), 1743-1766.

Sertakova, E.A., Koptseva, N.P., Kolesnik, M.A., Libakova, N.M., Luzan, V.S., \& Sergeeva, N.A. (2016). Brand-management of Siberian Cities (Krasnoyarsk as a case study). In International Review of Management and Marketing, 6(5S), 185-191.

Smolina, M.G. (2013). Otnosheniia zritelia i khudozhestvennogo prostranstva $\mathrm{v}$ tvorchestve D.I. Karatanova [Relationship of the viewer and the artistic space in D. I. Karatanov's works]. In Sibirskaia zaimka. Istoriia Sibiri vnauchnykh publikatsiiakh [Siberian hunter's cabin. History of Siberia in scientific publications], available at: http://zaimka.ru/smolina-karatanov/

Seredkina, N.N. (2015). Cultural and Semiotic Strategies of Constructing Indigenous Northern Ethnicity in Art (Based on the Yakut Art School). In Journal of Siberian Federal University. Humanities \& Social Sciences, 4(8), 769-792.

Seredkina, N.N., Koptzeva, N.P. (2018a). International and Russian Practices of Preserving and Reproducing the Languages of the Small-numbered Indigenous Peoples 
of the North. In Journal of Siberian Federal University. Humanities \& Social Sciences, 12(11), 2056-2077.

Seredkina, N.N., Smolina, M.G. (2018b). Educational potential of epics and fairy tales of indigenous minority peoples of Siberia. In Novosibirsk State Pedagogical University Bulletin, (4), 217-232.

Seredkina, N.N., Strucheva, Ye.S. (2018c). Revival of the Evenki Language: Traditional and Modern Formats. In Journal of Siberian Federal University. Humanities \& Social Sciences, 4(11), 615-628.

Singh, P. (2018). Global configurations of indigenous identities, movements and pathways. In Thesis Eleven, 145(1), 10-27.

Sitnikova, A.A., Pimenova, N.N., Fil'ko, A.I. (2018) Pedagogical approaches to teaching and adaptation of indigenous minority peoples of the North in higher educational institutions. In Novosibirsk State Pedagogical University Bulletin, 8 (4), 26-45.

Tatarko, A.N., Lebedeva, N.M. (2011). Metody etnicheskoi i kross-kul'turnoy psikhologii [Methods of ethnic and cross-cultural psychology]. Moscow, Izdatel'skii dom Vysshei shkoly ekonomiki, 238 p.

Zamaraeva, Yu.S. (2018). Experience in the Preservation and Development of the Evenki Language in the Evenki Municipal District of the Krasnoyarsk Krai on the Basis of the Analysis of Evenki Archival Documents. In Journal of Siberian Federal University. Humanities \& Social Sciences, 8(11), 1327-1369.

\title{
Этнокультурная идентичность в произведениях красноярских художников
}

\author{
М. А. Амосова ${ }^{a}$, Н. П. Копцева ${ }^{\text {, }}$ А. А. Ситникова ${ }^{a}$, \\ Н. Н. Середкина ${ }^{a}$ Ю.С. Замараева ${ }^{\text {a }, ~ А . ~ В . ~ К и с т о в а ~}{ }^{a}$, , \\ К. В. Резникова ${ }^{a}$, М. А. Колесник ${ }^{\text {a }}$, Н. Н. Пименова ${ }^{\text {a }}$ \\ ${ }^{a}$ Сибирский федеральный университет \\ Россия, 660041, Красноярск, пр. Свободньй, 79 \\ ${ }^{6}$ Красноярский художественный музей им. В. И. Сурикова \\ Россия, 660049, Красноярск, \\ ул. Карла Маркса, 36 / ул. Парижской Коммуны, 20
}

Статья посвящена проблеме осмысления и отражения этнокультурной идентичности коренных народов в произведениях изобразительного искусства. Авторы рассматривают особенности визуализации образа коренных народов Севера в творчестве художников Красноярского края на материале анализа наиболее репрезентативных 
произведений живописи и графики: картина Константина Семеновича Войнова «Заполярная Мадонна» (2009), картина Андрея Прокофьевича Лекаренко "Девушка с Таймьра» (1959) и картина Валерия Иннокентьевича Кудринского «Северянка» (1985).

Анализ осуществляется с опорой на конструктивистский подход $к$ идентичности и принципь современной теории изобразительного искусства В. И. Жуковского и Н.П. Копиевой.

В результате выделяются три ключевых этапа развития интереса к образам коренных народов Севера в творчестве красноярских художников от начала ХХ века до начала ХХІ века, определяются два основных подхода к изображению образа жизни коренных народов Севера: документально-этнографический и философский.

Ключевые слова: этнокультурная идентичность, Арктика, коренные народы Севера, изобразительное искусство, Красноярский край, красноярские художники.

Научная специальность: 17.00.00-искусствоведение; 24.00.00-культурология. 